\title{
PENGGUNAAN MODEL PEMBELAJARAN KOOPERATIF TIPE STUDENTS TEAM ACHIEVEMENT DIVISION (STAD) SEBAGAI UPAYA MENINGKATKAN PRESTASI BELAJAR AGAMA HINDU
}

\author{
Ni Wayan Rami \\ SD Negeri 3 Sukawati \\ niwynrami@gmail.com
}

\begin{abstract}
Abstrak
Penelitian ini dilaksanakan di SD Negeri 3 Sukawati di Kelas II B yang kemampuan siswanya untuk mata pelajaran Agama Hindu masih cukup rendah. Tujuan penulisan penelitian tindakan kelas ini adalah untuk mengetahui apakah model pembelajaran Kooperatif Students Team Achievement Division (STAD) dapat meningkatkan prestasi belajar siswa. Metode pengumpulan datanya adalah tes prestasi belajar. Metode analisis datanya adalah deskriptif. Hasil yang diperoleh dari penelitian ini adalah model pembelajaran Kooperatif Students Team Achievement Division (STAD) dapat meningkatkan prestasi belajar siswa. Ini terbukti dari hasil yang diperoleh pada awalnya rata-rata prestasi belajar yang diperoleh adalah 68,09, pada siklus I meningkat menjadi 72,61 dan pada siklus II menjadi 79,76. Kesimpulan yang diperoleh dari penelitian ini adalah model pembelajaran Kooperatif Students Team Achievement Division (STAD) dapat meningkatkan prestasi belajar Agama Hindu siswa kelas II B SD Negeri 3 Sukawati Semester II Tahun Pelajaran 2018/2019.
\end{abstract}

Kata kunci: model pembelajaran Kooperatif Students Team Achievement Division (STAD), prestasi belajar.

\begin{abstract}
This research was conducted at SD Negeri 3 Sukawati in Class II B where the ability of students for Hindu subjects was still quite low. The purpose of writing this class action research is to find out whether the Cooperative Students Team Achievement Division (STAD) learning model can improve student achievement. The data collection method is a learning achievement test. The data analysis method is descriptive. The results obtained from this study are the Cooperative Students Team Achievement Division (STAD) learning model can improve student achievement. This is evident from the results obtained at first the average learning achievement obtained was 68.09, in the first cycle increased to 72.61 and in the second cycle to 79.76. The conclusion obtained from this study is that the Cooperative Students Team Achievement Division (STAD) learning model can improve the learning achievement of Hindu Religion students of class II B of SD Negeri 3 Sukawati Semester II in the 2018/2019 Academic Year.
\end{abstract}

Keywords: Students Achievement Division (STAD) cooperative learning model, learning achievement.

\section{Pendahuluan}

Paradigma pendidikan Indonesia dewasa ini mengalami pergeseran yakni mengajar bukan lagi usaha untuk menyampaikan ilmu pengetahuan, melainkan juga usaha menciptakan system lingkungan yang membelajarkan subjek didik agar tujuan pengajaran dapat tercapai secara optimal. Mengajar dalam pemahaman ini memerlukan suatu strategi pembelajaran yang efektif. Mutu pengajaran tergantung pada pemilihan strategi yang tepat dalam upaya mengembangkan kreativitas, kemampuan, dan sikap inovatif peserta didik. Untuk itu perlu dibina dan dikembangkan kemampuan professional guru untuk mengelola program pengajaran dengan strategi pembelajaran yang kaya dengan variasi.

Untuk bisa menyelesaikan dan merubah individu agar takwa terhadap Tuhan Yang Maha Esa tidaklah gampang.Hal tersebut harus dilakukan lewat pembiasaan dan dilakukan dengan sangat gigih dalam pembelajaran.Usaha untuk tersebut tentu harus dibarengi dengan penanaman pengertian-pengertian, pengetahuan-pengetahuan, pemahaman-pemahaman serta dilakukan dengan sungguh-sungguh.

Upaya mencerdaskan kehidupan bangsa dan mengembangkan kualitas manusia seutuhnya adalah misi pendidikan yang menjadi tanggung jawab profesional setiap guru. Guru tidak cukup hanya menyampaikan materi pengetahuan kepada siswa di kelas tetapi dituntut juga untuk meningkatkan kemampuan guna mendapatkan pengetahuan dan pemahaman serta menyampaikan informasi yang dimiliki sesuai dengan kebutuhan profesinya melalui proses pembelajaran yang baik.

Pembelajaran pada dasarnya adalah proses penambahan informasi dan kemampuan baru. Mengacu pada kurikulum yang ada menyangkut informasi dan kemampuan apa yang harus dimiliki oleh siswa, maka pada saat 
itu juga kita semestinya berpikir strategi apa yang harus dilakukan agar semua itu dapat tercapai secara efektif dan efisien. Ini sangat penting untuk dipahami, pengetahuan tentang apa yang harus dicapai akan menentukan bagaimana penjabaran pemahaman guru tentang cara atau strategi untuk mencapainya.

Keberhasilan proses pembelajaran lebih banyak ditentukan oleh kemampuan guru dalam mengelola proses pembelajaran tersebut. Kadang ada guru yang disebut pintar tetapi lemah dalam menyampaikan pengetahuan dan pemahaman yang ada dalam dirinya maka tentu proses pembelajaran tidak akan berhasil dengan baik. Kadang ada guru yang disebut tidak terlalu pintar tetapi dalam menyampaikan dan mengelola pembelajaran lebih kreatif dan memahami cara penyampaiannya bisa jadi menyebabkan proses pembelajaran akan berhasil dengan baik. Di antara keduanya tentu yang paling sesuai adalah memiliki kemampuan profesionalisme keguruan dan mampu menyampaikan dengan baik demi terciptanya proses dan tujuan pembelajaran yang diharapkan untuk mampu meningkatkan ketakwaan terhadap Tuhan Yang Maha Esa.

Sehubungan dengan proses pembelajaran yang berlangsung di SD Negeri 3 Sukawati dari hasil pengumpulan data awal didapat nilai rata-rata siswa Kelas II B pada mata pelajaran Agama Hindu baru mencapai 68,09. Hasil tersebut tentu tidak sesuai dengan harapan keberhasilan pendidikan yang ditetapkan yaitu 75,00. Hal ini dikarenakan pembelajaran yang monoton diterapkan oleh guru, sehingga siswa kurang antusias dalam mengikuti pembelajaran Agama Hindu di kelas.

Untuk mengatasi permasalahan di atas, diterapkan model pembelajaran Student Teams Achievement Division. Model ini di design untuk tim kecil yang berjumlah 4-5 orang yang masing-masing tim itu bisadiatur tingkat kemampuan siswanya maupun gendernya. Guru menyajikan pelajaran, kemudian siswa bekerja bertim dan memastikan agar masing-masing individu dalam tim dapat pekerjaan yang dikerjakan dan masing-masing tim meyakinkan dirinya agar anggotanya dapat menguasai pelajaran yang diberikan oleh gurunya.

Menurut Slavin (1995:5) pada awalnya teori itu mendapat soal yang dikerjakan oleh masing-masing anggota tim, pada saat awal tersebut masing-masing anggota tim tidak saling membantu, artinya mereka pada awalnya bekerja sendiri-sendiri. Apabila salah satu anggota tim menemui kesulitan diharapkan anggota tim yang lain dapat menolongnya.

Berdasarkan pemaparan di atas, maka pada penelitian ini akan mengambil judul tentang Penggunaan Model Pembelajaran Kooperatif Tipe Students Team Achievement Division (STAD) Sebagai Upaya Meningkatkan Prestasi Belajar Agama Hindu Pada Siswa Kelas II B SD Negeri 3 Sukawati Semester II Tahun Pelajaran 2018/2019.

\section{Metode}

Penelitian yang dilakukan termasuk penelitian tindakan. Oleh karenanya, rancangan yang khusus untuk sebuah penelitian tindakan sangat diperlukan. Penelitian tindakan didasarkan pada filosofi bahwa setiap manusia tidak suka atas hal-hal yang statis, tetapi selalu menginginkan sesuatu yang lebih baik. Peningkatan diri untuk hal yang lebih baik ini dilakukan terus menerus sampai tujuan tercapai (Suharsimi Arikunto, Suhardjono, Supardi, 2006: 6-7).

Dalam melaksanakan penelitian, rancangan merupakan hal yang sangat penting untuk disampaikan. Tanpa rancangan, bisa saja alur penelitian akan ngawur dalam pelaksanaannya. Untuk penelitian ini penulis memilih rancangan penelitian tindakan yang disampaikan oleh Ebbut.

Pada daur I dimulai dengan adanya ide awal akibat temuan dan analisis yang telah dilakukan. Setelah ada temuan tersebut dibuatlah perencanaan umum sesuai langkah yang direncanakan baik tindakan 1, tindakan 2 maupun tindakan 3. Sesudah membuat perencanaan, diimplementasikan dalam tingkat 1, dimonitoring implementasinya serta efeknya kemudian dijelaskan kegagalan-kegagalan yang ada selama implementasinya lalu dibuat revisi umum untuk perencanaan tindakan selanjutnya.

Pada tindakan selanjutnya, perencanaan yang telah dibuat diimplementasikan, terus dimonitor implementasinya serta efek yang ada, dijelaskan setiap langkah implementasinya dan efeknya. Setelah mengetahui bagaimana hasil dan efeknya, dibuat lagi perencanaan untuk tindakan selanjutnya. Demikian beranjut sampai menemukan hasil yang sesuai tujuan yang direncanakan.

Untuk mengumpulkan data prestasi belajar Agama Hindu siswa digunakan tes prestasi belajar berupa soal pilihan ganda dan essay. Setelah data terkumpul, dilanjutkan dengan analisis data. Untuk menganalisis data hasil penelitian ini digunakan metode deskriptif. Untuk data kuantitatif dianalisis dengan mencari mean, median, modus, membuat interval kelas dan melakukan penyajian dalam bentuk tabel dan grafik.

Indikator keberhasilan penelitian yang diusulkan dalam penelitian ini pada siklus I dan II mencapai nilai rata-rata 75,00 dengan ketuntasan belajar 85\%. dengan KKM yang ditetapkan untuk mata pelarajan Agama Hindu pada SD Negeri 3 Sukawati adalah 75. 


\section{Hasil Dan Pembahasan}

Deskripsi yang dapat disampaikan untuk perolehan data awal sebagai indikator yang dituntut yaitu minimal siswa mampu mencapai ketuntasan belajar dengan nilai sama atau melebihi KKM. KKM yang dipatok berdasarkan ketentuan yang disepakati oleh dewan Guru dan Komite untuk mata pelajaran Agama Hindu adalah 75,00. Data yang diperoleh menunjukkan hanya 9 orang siswa yang tuntas dan 12 orang berada dibawah KKM, secara klasikal jumlah nilai diperoleh adalah 1430 dengan rata rata kelas adalah 68,09 atau hanya 42,85\% yang tuntas dari 21 siswa dikelas II B pada Semester II Tahun Pelajaran 2018/2019. Data tersebut menunjukkan rendahnya prestasi belajar siswa kelas II B pada proses pembelajaran awal. Kekurangan yang ada adalah akibat pembelajaran yang dilukan masih bersifat konfensional,kurang alat peraga dan kurang inovatif. Kelebihannya adalah peneliti sebagai guru telah giat melakukan pembelajaran secara maksimal. Maka peneliti sangat perlu melakukan perbaikan pembelajaran pada siklus I dengan menggunakan model pembelajaran STAD.

Pada siklus I, hasil yang diperoleh belum mencapai target dari indikator keberhasilan penelitian. Hal ini disebabkan oleh masih belum sempurnanya rancangan pembelajaran yang akan disampaikan guru. Namun pada siklus I sudah menunjukan peningkatan minat siswa dalam mengikuti pembelajaran yaitu dari data awal yang hanya mencapai rata-rata 68,09 meningkat menjadi 72,61. Sedangkan presentase ketuntasan meningkat dari $42,85 \%$ pada data awal menjadi $71,42 \%$ pada siklus I.

Pada siklus ke II perbaikan prestasi belajar siswa diupayakan lebih maksimal dengan peneliti membuat perencanaan yang lebih baik, menggunakan alur dan teori dari metode/model pembelajaran kooperatif tipe STAD dengan benar dan lebih maksimal. Peneliti giat memotivasi siswa agar giat belajar, memberi arahanarahan, menuntun mereka untuk mampu menguasai materi pelajaran pada mata pelajaran Agama Hindu lebih optimal. Akhirnya dengan semua upaya tersebut peneliti mampu meningkatkan prestasi belajar siswa pada siklus II menjadi rata-rata 79,76. Upaya-upaya yang maksimal tersebut menuntun pada suatu keberhasilan bahwa model/metode pembelajaran kooperatif tipe STAD mampu meningkatkan prestasi belajar Agama Hindu Siswa kelas II B SD Negeri 3 Sukawati Semester II Tahun Pelajaran 2018/2019.

Perkembangan peserta didik pada siklus II ini adalah 21 orang anak yang diteliti, ada 1 anak yang mendapat nilai di bawah KKM, 7 anak mendapat nilai sama dengan KKM dan 13 anak mendapat nilai diatas KKM artinya mereka sudah berkembang sesuai indikator, mereka sudah giat belajar, sudah aktif dalam belajar. Anak-anak ini termasuk anak yang aktif dalam belajar. Dari semua data yang sudah diperoleh tersebut dapat diberi sintesis bahwa semua anak sudah mampu melakukan semua indikator yang diharapkan.

Semua hasil yang diperoleh dari awal, siklus I dan siklus II dipaparkan dalam bentuk tabel seperti berikut:

Tabel 1. Data Prestasi Belajar Siswa kelas II B SD Negeri 3 Sukawati

\begin{tabular}{llll}
\hline DATA & \multicolumn{1}{c}{ AWAL } & \multicolumn{1}{c}{ SIKLUS I } & \multicolumn{1}{c}{ SIKLUS II } \\
\hline Rata Rata Klasikal & 68,09 & 72,61 & 79,76 \\
Persentase Ketuntasan & $42,85 \%$ & $71,42 \%$ & $95,23 \%$ \\
\hline
\end{tabular}

Model pembelajaran Kooperatif Students Team Achievement Division (STAD) memiliki langkah-langkah mengutamakan membantu kegiatan akademik, mengupayakan hubungan kelompok yang harmonis, mengembangkan harga diri siswa, meningkatkan pencapaian akademik siswa pada awalnya bekerja sendirisendiri, kalau ada kendala baru anggota timnya yang membantu. Dimulai penilaian dengan skor individu kemudian baru skor perbaikan dari masing-masing tim. Hal semacam inilah yang diupayakan untuk memecahkan masalah. Guru dalam hal ini hanya sebagai motivator dan fasilitator. Model ini menuntut kegiatan intelektual yang tinggi, memproses apa yang mereka telah dapatkan dalam pikirannya untuk menjadi sesuatu yang bermakna. Mereka diupayakan untuk lebih produktif, mampu membuat analisa membiasakan mereka brpikir kritis, dapat mengingat lebih lama, materi yang telah mereka pelajari. Model ini juga bisa diupayakan untuk pengembangan kemampuan akademik.

Hasil penelitian ini diperkuat dengan hasil penelitian oleh Yudiasa pada tahun 2016 yang berjudul Penerapan Model Pembelajaran STAD untuk Meningkatkan Motivasi dan Hasil Belajar IPA Kelas V. Berdasarkan observasi motivasi, persentase rata-rata motivasi siswa pada siklus I sebesar 75,75\% dengan kategori sedang, dan persentase rata-rata motivasi siswa pada siklus II sebesar $84,00 \%$ dengan kategori tinggi. Berdasarkan tes hasil belajar IPA, persentase rata-rata hasil belajar IPA siswa pada siklus I sebesar 78,00\% dengan kategori sedang, dan persentase rata-rata hasil belajar IPA siswa pada siklus II sebesar 86,00\% dengan kategori tinggi. Berdasarkan hasil penelitian tersebut dapat disimpulkan bahwa penerapan model pembelajaran kooperatif tipe STAD berbantuan media grafis dapat meningkatkan motivasi dan hasil belajar IPA siswa kelas V di SD Negeri Sekaan tahun pelajaran 2015/2016.

Selanjutnya hasil penelitian yang dilakukan oleh Marini pada tahun 2014 yang berjudul Penerapan Model Pembelajaran Kooperatif Tipe Stad Untuk Meningkatkan Hasil Belajar di Sekolah Dasar. Hasil penelitian menunjukkan adanya peningkatan persentase aktivitas guru dan siswa pada siklus I dan siklus II. Aktivitas guru 
mengalami peningkatan sebesar $23,75 \%$ yaitu dari $67,79 \%$ pada siklus I menjadi $86 \%$ pada siklus II. Sedangkan aktivitas siswa mengalami peningkatan sebesar $19,30 \%$, yaitu dari $73,2 \%$ pada siklus I menjadi $89,25 \%$ pada siklus II. Hasil belajar yang diperoleh siswa kelas I SDN Jotangan Mojosari Mojokerto mengalami peningkatan. Ketuntasan belajar siswa secara klasikal mengalami peningkatan sebesar pada mata pelajaran Bahasa Indonesia 74\% dan matematika 71\% pada siklus I menjadi 91\% padamata pelajaran Bahasa Indonesia dan $91 \%$ pada mata pelajaran matematika pada siklus II. Berdasarkan hasil yang diperoleh dapat disimpulkan bahwa penerapan model pembelajaran kooperatif tipe STAD dapat meningkatkan hasil belajar siswa.

\section{Simpulan}

Berdasarkan pemaparan di atas, dapat disimpulkan bahwa penggunaan model pembelajaran kooperatif tipe Students Team Achievement Division (STAD) sangat efektif digunakan untuk meningkatkan prestasi belajar Agama Hindu pada siswa kelas II B SD Negeri 3 Sukawati Semester II Tahun Pelajaran 2018/2019.

Berdasarkan simpulan di atas, dapat disampaikan saran-saran sebagai berikut:

1. Bagi siswa, siswa disarankan untuk selalu giat belajar dan meningkatkan kerjasama antar siswa dalam mencapai tujuan pembelajaran di kelas.

2. Bagi guru kelas, apabila mau melaksanakan proses pembelajaran penggunaan model yang telah diterapkan ini semestinya menjadi pilihan dari beberapa model yang ada mengingat model/metode ini telah terbukti dapat meningkatkan prestasi belajar siswa.

3. Bagi peneliti lain, walaupun penelitian ini sudah dapat membuktikan efek utama dari model pembelajaran kooperatif tipe STAD dalam meningkatkan prestasi belajar, sudah pasti dalam penelitian ini masih ada halhal yang belum sempurna dilakukan, oleh karenanya disarankan kepada peneliti lain yang berminat meneliti topik yang sama untuk meneliti bagian-bagian yang tidak sempat diteliti.

\section{Daftar Pustaka}

Arikunto, Suharsimi; Suhardjono; Supardi. 2006. Penelitian Tindakan Kelas. Jakarta: PT Bumi Aksara.

Dahar, Ratna Wilis. 1989. Teori-Teori Belajar. Jakarta: Penerbit Erlangga.

Dimyati dan Mudjiono. 2001. Belajar dan Pembelajaran. Jakarta: Dirjen Dikti.

Djamarah, Syaful Bahri. 2002. Prestasi Belajar dan Kompetensi Guru. Surabaya: Usaha Nasional.

Gagne, Robert M. 1977. The Conditions of Learning. Third Edition. New York: Holt, Reinhart and Winston.

Gay, L. R. 1987. Educational Research: Competencies for Analysis and Application. Seventh Edition. Columbus, Ohio: Merrill Publishing Company.

Hilke, Eileen Veronica. 1998. Fastback Cooperative Learning. New York: McGraw-Hill, Inc.

Johnson, David W. and Roger T. Johnson. 1984. Cooperation in the Classroom. Edina,Minnesota: A publication Interaction Book Company.

Marini, Reny. 2014. Penerapan Model Pembelajaran Kooperatif Tipe Stad Untuk Meningkatkan Hasil Belajar di Sekolah Dasar. E-Jurnal Penelitian Pendidikan Guru Sekolah Dasar Volume 2 Nomor 3.

Slavin, Robert E. 1995. Cooperative Learning Theory, Research and Practice Massachusett. USA: Allymand \& Bacon.

Yudiasa, I Kadek. 2016. Penerapan Model Pembelajaran STAD untuk Meningkatkan Motivasi dan Hasil Belajar IPA Kelas V. E-Jurnal Mimbar PGSD Undiksha Volume 4 Nomor 3. 